\title{
Karst-Induced Geoharzards in Kenya's Coastal Region: A Case Study of Vipingo Coral Limestone Quarry
}

\author{
Joan A. Onyango and Dyson N. Moses
}

\section{ABSTRACT}

\begin{abstract}
As the human population grows, the demand for space to settle and infrastructure development puts a strain on land resources hence people move to occupy areas of difficult terrain such as mountainous regions and karst environments. The trends in anthropogenic activities mean that there will be increased human interaction with the perilous terrain and consequently geohazards associated with them. Studies on geohazards in Kenya have focused mostly on landslides in mountainous regions but not much has been reported on geohazards that are common in areas of carbonate rocks such as coral limestone. Vipingo coral limestone quarry, a coastal quarry, is taken as a case study as a number of hazardous situations have been encountered during mining. This paper outlines the karst features, their formation processes in the coralline limestone rock mass, and the resultant geohazards. Field visits made to the quarry complemented with previous exploration reports enabled the collection of field data on rock mass characteristics, karst features, and potential hazardous sites were mapped out. Karstification is evident in traces of pores and fissures filled with soil in the upper layers of the rock. Cavities, voids, and caves occur randomly in the rock mass and are the genesis of incidents such as bench collapse, sagging of overlying rock slaps leading to sinkholes. The rock mass is weak and prone to slope failures. Suggestions have been fronted for geohazard mitigation and further research work for the scientific community. Thus, this work constitutes an important knowledge base for infrastructure development and any other quarries around the area, and for those who are settled around this karst environment in order to preempt geo-accidents.
\end{abstract}

Keywords: Carbonate rock, caves, karst unit, mitigation, sinkholes.
Published Online: September 24, 2021

ISSN: $2684-446 \mathrm{X}$

DOI : $10.24018 /$ ejgeo.2021.2.5.158

\section{J. A. Onyango*}

Jomo Kenyatta University of Agriculture and Technology, Nairobi, Kenya.

(e-mail: jaonyango@jkuat.ac.ke)

D. N. Moses

Kyushu University, Japan.

(e-mail: dysonmoses@gmail.com)

*Corresponding Author

\section{INTRODUCTION}

Regions of karst are found on all the continents of our beautiful planet. It is estimated that about $20 \%$ of the earth's continental ice-free landmass is covered in carbonate and evaporite rocks on which karst landscapes do develop [1]. In describing landforms of the earth, Francisco Gutiérrez \& Gutiérrez [2] state the origin of the word karst as coming from a limestone region bestriding Slovenia and Italy where kras is Slovenian and carso is Italian. In the development process of karst terrain, the excavating effects of water on carbonates and evaporites both at the surface and subsurface override mechanical erosion forming distinctive features such as barren/rocky ground, caves, sinkholes, underground rivers, and the absence of surface streams and lakes. The morphology of the karst terrain can be classified into three either bare (soluble rocks are exposed), covered/mantled by unconsolidated deposits or interstratal karst overlain by cap rocks (non-karst rocks).

As previously mentioned, karst terrains are developed mainly on carbonate and evaporite rocks. There are however significant differences in their properties such as solubility and mechanical strength, which lead to peculiarities in their karst features. Evaporites for instance have higher solubilities than carbonates since they tend to contain more soluble salts. The most common evaporite minerals, i.e. gypsum and halite, have solubilities of $2.4 \mathrm{gL}^{-1}$ and $360 \mathrm{gL}^{-1}$, respectively whereas the most common carbonate minerals, i.e. calcite and dolomite, generally have solubilities below $0.1 \mathrm{gL}^{-1}$ [3] The result of higher solubility in evaporites is that karst features form and evolve much faster than in carbonate rocks. Moreover, outcrops are comparably less abundant than those of carbonate rocks, especially in humid areas. The other property difference is that evaporites have lower mechanical strength and higher ductile rheology compared to carbonates as the higher solubilities considerably weaken their rock mass structure. This explains why geohazards such as sinkholes and rock failures in scarps and cavities are more prone to evaporite rocks than carbonates.

Karst terrain tends to be one of the most fragile and susceptible environments on the earth's continental mass mainly due to the hydrologic, geomorphologic and hydrogeological features of karst [4]. The presence of evaporite and carbonate rocks alone doesn't however directly imply the presence of karst. The formation of karst is largely dependent on aspects such as bedrock type and purity, 
physiographic location, and biogeoclimatic setting [5]. Bedrock purity, which is one of the most important controls in karst development, is defined by Ford \& Williams [6] as the percentage of the most important mineral salts making up the evaporite $\left(\% \mathrm{CaSO}_{4} \cdot 2 \mathrm{H}_{2} \mathrm{O}\right)$ or carbonate $\left(\% \mathrm{CaCO}_{3}\right)$ structure. The higher the percentage of the important mineral, the purer the rock and consequently the higher its latency for karst development.

The process of identifying karst features involves delineating a karst landscape unit, or basically a "karst unit," which is defined as "a three-dimensional belt or block of soluble bedrock area surrounded by other less soluble rock types. The karst unit can then be broken down into three parts namely exokarst, epikarst and endokarst [7] as illustrated in Fig. 1. Exokarst is a term that describes all features found on the surface of the karst landscape, ranging from small-scale to large-scale features such as karren, sinkholes, poljes. Epikarst is the zone of openings or fractures enlarged by solution extending from the surface to about $10-30 \mathrm{~m}$ below the surface. The endokarst encompases all deeper components of the subsurface karst landscape, including the smallest cavities, cave speleothems, cave sediments, and cave passages. Consequently, the epikarst zone plays a crucial role in karst system development and evolution by letting water, air, and other materials (sediment, organic debris, and nutrients) be readily transported underground [8].

As humans continue to interact with karst environments around the world more and more information is shared about karst terrains, their development processes, morphological features, and associated geohazards. Komac \& Zorn [9] gave a definition of a geohazards as geomorphological, geological, or environmental processes, phenomena, and conditions that are potentially precarious or pose a level of danger to human life, health, and property, or to the environment.

The geohazards can be natural (neither provoked nor dependent on man and his activities) or of anthropogenic origin (directly caused by man or can be directly linked to human activities disrupting the natural stress balance in the rock mass structure) [10]. Human activities contribute to hazards in such ways as building structures above irregular bedrock surfaces which induce differential compaction of soils above the bedrock [11]. Underground cavities built by man which are abandoned and forgotten over time become a major inducer of subsidence when they, later on, become parts of built-up areas [12]. Quarrying is one of the most destructive human activities in karst areas as it causes degradation of the landscape and changes in natural hydrography [13]. It can also lead to new or concealed sinkholes and cave systems opening up resulting in setting or catastrophic collapse of the ground. Underground quarries may also result in land subsidence as a result of instability problems underground.

Geological literature indicates that the most distinguishable phenomenon that shapes the landscape in an area of carbonate rock is karst processes, exerting a very strong influence on the engineering geological environment in relation to land use and regional planning activities [14]. Consequently, engineering practice confirms that the complexity of local engineering-geological conditions in a karst environment is evaluated based on a complex analysis of four geological environmental elements namely: the morphology, geological structure and properties of rocks, hydrogeological conditions, and the activity and degree of development of various exodynamic processes [15]. Even in flat karst regions, as is the low-lying coastal area of Kenya, rock failures may be common as a result of predisposing factors such as the presence of voids and conduits and the resultant circulation of water [16]. The major potential hazards encountered in a karst geological environment include sinkholes, subsurface karst forms such as caverns, caves, karst shafts, rock slope failures, etc.

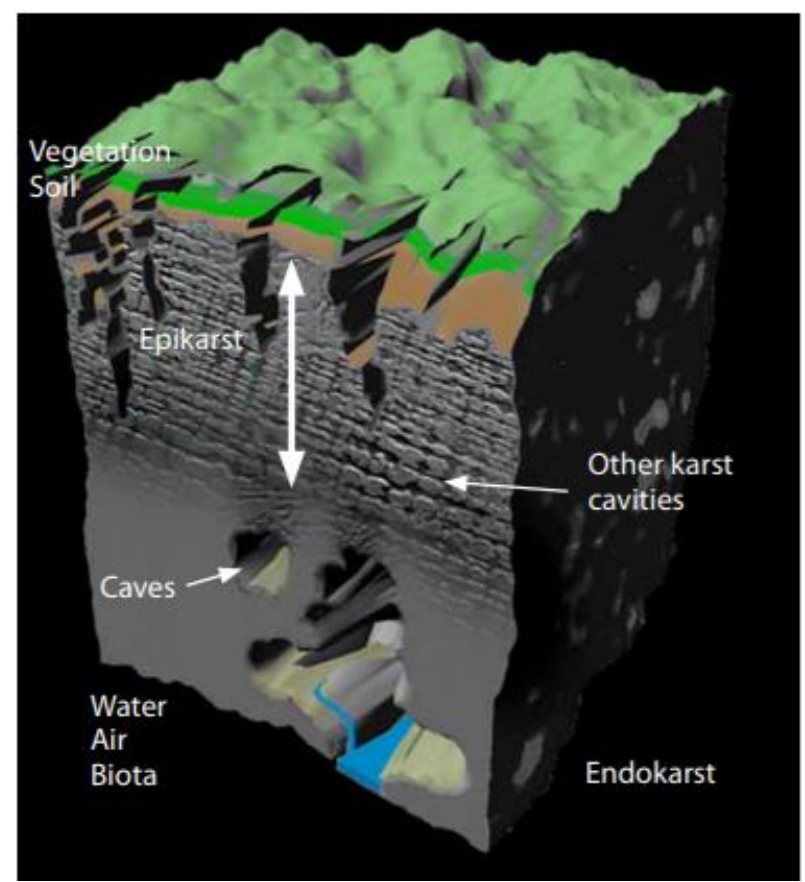

Fig. 1. A karst unit (Adapted from Stokes et al. [5]).

Kenya's geological structure consists mostly of a stable landmass with little tectonic activity except within the Rift Valley which has drawn lots of attention in the recent past. Geohazards are not quite common except in the mountainous regions which sometimes suffer landslides during heavy rains. Mining and construction activity are major contributors to geo-accidents in the country by leaving out large and deep dug up spaces with steep slopes. Construction stone, granite, ballast, and crystalline limestone quarries tend to have competent rock but the presence of bedding planes and structural discontinuities in the rock fabric compromise the competency of the rock mass. Furthermore, quarry benches and overall pit slopes are often kept steep, vertical/subvertical, with some of the quarries reaching up to $100 \mathrm{~m}$ in depth. These steep quarry slopes are often the major cause of accidents such as slope failures in various modes, rockfalls. Ground collapse and subsidence have also been reported in underground mines. The rock mass characteristic of carbonate rocks where high porosity leads to excessive water trapping and consequent weakening of rock through solution weathering, is another source of hazards. This type of rock mass is common in the Rift Ralley, in Homa Hills, and along the coastal plain where coral limestone rock exists.

Taking a look at the level of risk posed by karst geohazards on various engineering projects, generally, the magnitude of inconvenience caused by karst features in a mine is a bit different from the challenges posed to a construction project 
in that since mining involves excavating material, the karst features get 'swallowed up' with the excavated material. The features may be a threat to safe mining if they are not detected in advance of an operation otherwise they become a big threat to the safety of the mine and its environs after abandonment.

Over time, studies on geohazards in Kenya have focused mainly on landslides in mountainous regions, so not much information is available on karst processes and associated geohazards in the country. The growing human population and the ensuing demand for settlement land, water, and energy resources have put a strain on safer and easy-toengineer land leaving mostly dangerous terrains including mountains and karst ecosystems. Man has to find a way of working on these difficult ecosystems as there will be an increase in interactions with karst environments. With more mining activity and engineering projects including human settlements altering the natural stability of the ground, it is likely that more and more geohazards will be encountered.

This paper details the karst-induced geohazards that are innate to the coralline limestone in the southeastern region of the Kenya's coast. It aims at bringing to the knowledge of the reader the hazards associated with this type of rock mass that is abundant along the coastal strip. More quarries are likely to be licensed to exploit coral limestone along the coastal belt and knowledge of the challenges their forerunners experienced plus how they handled the terrain will help guide their operations. The Vipingo Coral limestone quarry, a coastal quarry, is taken as a case study to give an idea of the characteristic karst features and the resulting geohazards. Mapping of geohazards in the quarry under study is important for the safety of operations in the quarry and also after abandonment. Post-closure, the mine will be open to the public as a nature trail and therefore it is important to have a knowledge of the geohazards inherent in the rock mass so as to anticipate any eventuality.

\section{The Study AREA}

\section{A. Geographical Location}

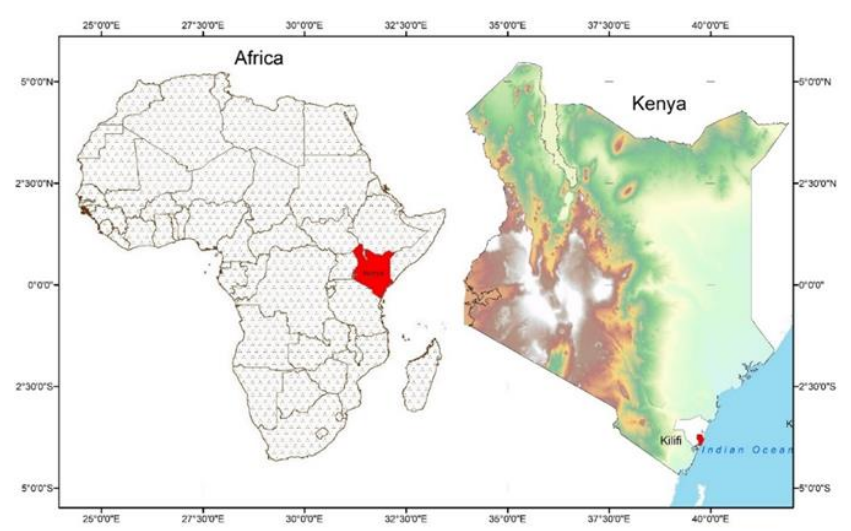

Fig. 2. Location of Vipingo quarry in Kilifi County, Kenya.

Vipingo Coral Limestone Quarry is situated in south-east Kenya in the coastal county of Kilifi which lies between latitude $20^{\prime}$ and $40^{\prime}$ South, and between longitude 39 05' and $4014^{\prime}$ East (Fig. 2). The quarry itself falls between latitudes 30 50'03" and $3051^{\prime} 27^{\prime \prime}$ South, and longitudes $39047^{\prime} 47^{\prime \prime}$ and $39049^{\prime} 18^{\prime \prime}$ parallel to the shoreline of the Indian Ocean. Limestone deposits extend approximately $180 \mathrm{k} \mathrm{N}-\mathrm{S}$ along the coastal zone from the Tanzania border to the Malindi area, the resource forming a $4-8 \mathrm{~km}$ wide band about $70 \mathrm{~m}$ thick running parallel to the coast [17]. Fig. 3 shows the Vipingo limestone quarries and reserve land extending in a strip of almost $4 \mathrm{~km}$ long and about $2 \mathrm{~km}$ wide, parallel to and at about $50 \mathrm{~m}$ distance from the shoreline. Topography of the area is more or less flat, at a height of $12-20 \mathrm{~m}$ above groundwater level. Most of the area lies on coral limestone, a fossil coral reef, acquired as limestone reserve, and is covered with shallow but fertile soil. All rainwater is drained naturally through the highly porous coral limestone to the sea.

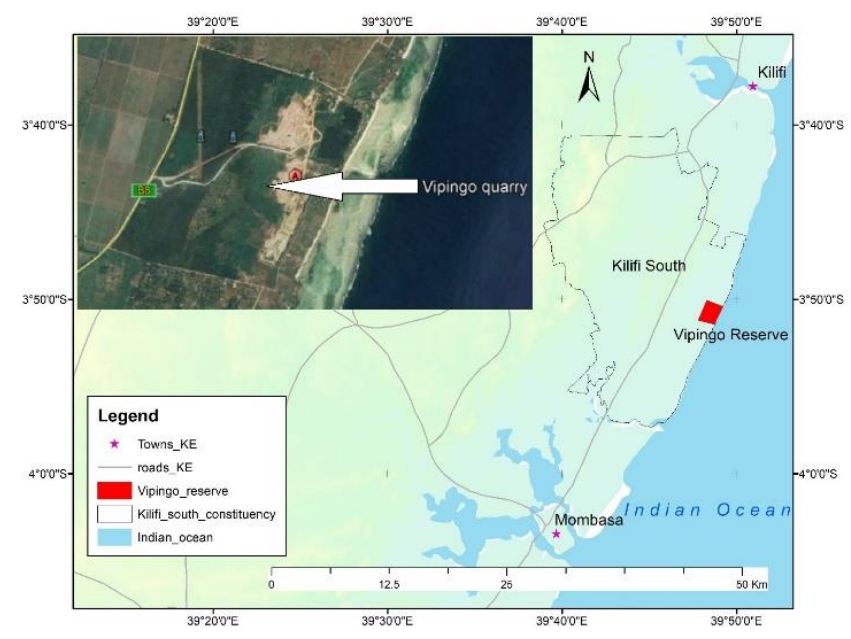

Fig. 3. The Vipingo quarry reserve.

\section{B. Geological Background}

The Kenyan coastal belt is divided into three parallel physiographic units which are closely related to the sedimentary units comprising the belt namely the Coastal Plain, the Foot Plateau, and the Coastal Range [18] as shown in Fig. 4 below.

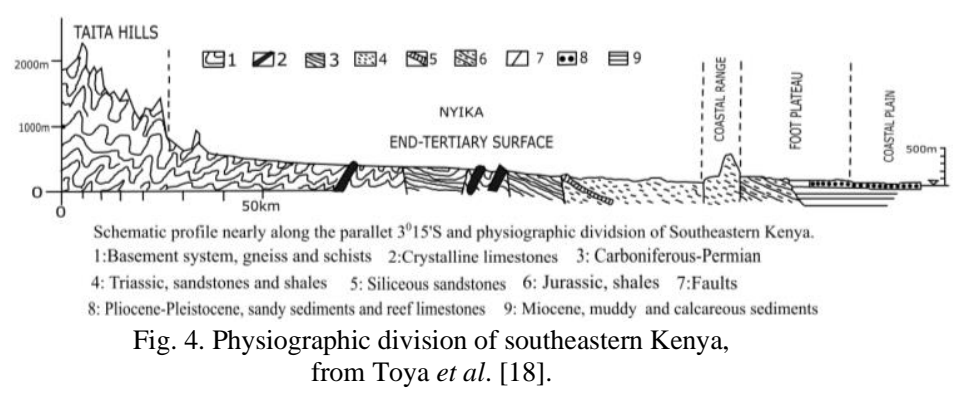

Vipingo area is in the Coastal Plain, which lies along the Indian Ocean Sea shore and reaches 3-8 km inland, with elevations mostly less than $33 \mathrm{~m}$. It consists mainly of Pleistocene deposits, of which the Pleistocene coral reef is the most relevant for the Vipingo quarry area. The Pleistocene coral reef is approximately $1-4 \mathrm{~km}$ wide, mostly around $20 \mathrm{~m}$ but up to $100 \mathrm{~m}$ thick, decreasing in thickness from the south towards the north [19], and extends along the whole length of the Kenyan coast from Tanzania to Malindi area [20]. Submarine thickness remains largely unknown.

The total carbonates content is about $95 \%$. The limestone is characterized by high textural porosities manifesting in density values as low as $0.5 \mathrm{~g} / \mathrm{cm}^{3}$ for in situ average of around $1.5 \mathrm{~g} / \mathrm{cm}^{3}$ which also allows high free silica content. 
Apart from structurally entrapped moderate to high silica values being present due to normal reef-building mechanisms. Aeolian free sand exacerbates the problem and generally tends to increase the variability in grade of the limestone. Silica content tends to increase downward towards the base of each coral unit and landwards in the shore direction. The former can be ascribed to the structure of the porous coral filled with fine-grained sand before lithifications and digenesis, while the latter may be ascribed to the normal lateral facies changes associated with marine transgression and regression cycles. This basal part of the Pleistocene reef units is colloquially described as the sandy facies.

In well-defined areas, the coralline body has been subjected to intensive karstifications and resultant voiding or caving. It also makes for a free silica source with two free silica sources identified. The first comes from free silica entrapped inside the pores and voids of the coral reefs and the second from the red ferruginous sandy (overburden topsoil) sediment which is located mainly on the most upper 2 meters of the deposits.

Braithwaite [21] documented a depositional history of the late Pleistocene limestone of the Kenya coast that was characterized by fluctuating sea levels resulting in various types of sediments. The reef would grow upwards during rising sea levels and expand laterally during stagnation, causing a heterogeneous mix of weathered limestone, clays, and sand. Low water levels during glacial periods would then expose the reef surface to erosion, weathering, and karstification.

Pleistocene formations identified along the coastal plain from the west to the east are the Holocene (recent) reef deposits, Shanzu calcarenites member, Mombasa limestone member, and the Kilindini sands member (Fig. 5). The reef deposits consist of an assemblage of coral limestone, calcarenites, and intercalations of quartz sands, sandstone pebbles, silt, and calcareous algae. This reef formation extends $3-5 \mathrm{~km}$ from the present shoreline, underlying the coastal plain, and attains elevations of up to $30 \mathrm{~m}$ above sea level. The Kilindini sands comprise mainly quartz sands with subordinate silts and clay [22].

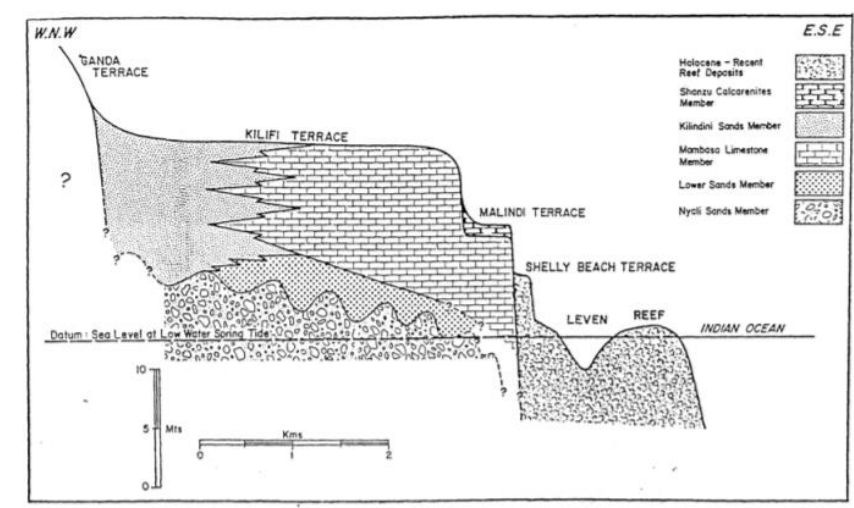

Fig. 5. Coastal terraces, stratigraphy, and diagrammatic cross-section of the Southern Coast of Kenya [19].

From the sea inland, the Pleistocene sediments can be divided into four categories which were identified by Pulfrey [23] and classified into four groups as coral reefs, coral breccias, sandstones, and sands. A more detailed description of the four sediment groups is as follows:

a) Fossil Reef (coral reef): Extends up to $2 \mathrm{~km}$ inland and consists of a tough white-yellow limestone which is rather dense, being purest on the east of the deposit. Most of the rock consists of shell and coral debris rather than grown coral structures but is highly heterogeneous.

b) Back Reef Zone (coral breccias): this brecciated calcareous rock is rarely exposed and is mostly observed when wells are dug. It's highly weathered coral limestone, which may represent a higher age, or reflect a karstification process caused by slightly acidic water flowing from adjacent Kilindini sand formations. It contains numerous karst depressions of varying sizes.

c) Clay Zone(sandstones): formed from fine sediments from estuarine or lagoonal deposits, the depth usually varied. It may overlay brecciated rock of the Back-Reef Zone.

d) Sandy Facies(sands): They extend 2-3 km and are of unknown thickness (maximum measured is $75 \mathrm{~m}$ in some wells). These diverse deposits contain fine to coarse to gravelly sands with embedded layers of clays and limestone. It is generally called 'Kilindini formation', and reflects a lagoonal origin, with locally strong deltaic, Fluviatile and windblown components. They occur immediately east of the foot plateau.

\section{Climate}

The coast of Kenya is a hot tropical region. Kilifi county has a moderately hot and dry climate throughout the year[24]. It is generally classified as sub-humid to semi-arid lowland characterized by the fairly hot and humid climate that gets hotter and drier towards the hinterland [25]. The weather conditions here are influenced by the largescale pressure systems and monsoon winds of the Indian ocean making two distinct monsoon seasons: northeast monsoon from December to March and southeast monsoon from May to October [22].

Rainfall distribution is weakly bimodal with an annual mean of about $1200 \mathrm{~mm}$. The wettest period is usually between late March to early June, and some short rains between October and November, January and February being the driest months [26]. The average annual temperatures are between a maximum of $300{ }^{\circ} \mathrm{C}$ and a minimum of $230{ }^{\circ} \mathrm{C}$ but never go beyond $330{ }^{\circ} \mathrm{C}$ in the hottest months between January to mid-March [27].

There's no substantial variation in the length of day over the course of the year in Kilifi, usually ranging within 20 minutes of 12 hours throughout [28]. The average daily sunshine is about 8.4 in July and 8.9 in February.

Relative humidity normally ranges between $60-70 \%$ in the afternoons and $92-94 \%$ at night with maximum average humidity for the year being 93\% and minimum average humidity for the year being $69 \%$ [29]. The highest overall humidity is recorded in April, May, June, and July whereas the lowest humidity occurs from January to March (60-62\%), coinciding with periods of highest temperature.

Mean annual potential evapo-transpiration ranges between 2100 and $2200 \mathrm{~mm}$ greatly exceeding the mean annual rainfall for the area, with mean annual potential evaporation estimated at $1400 \mathrm{~mm}$ [30]. The windiest time of the year at the Kenya Coast is during the Southeast Monsoon from May to September, while the calmest months are March and 
November when the winds are also more variable in direction [29]. The area experiences relatively low wind speeds ranging between $4.8 \mathrm{~km} / \mathrm{h}$ and $12 \mathrm{~km} / \mathrm{h}$ [24]. Wind follows a consistent daily pattern whereby wind strength drops during the night, being lowest at $0600 \mathrm{~h}$, peaking up in the course of the day, and dropping at night.

\section{Methodology}

Data collection in this study was done through a number of field visits and also a review of previous geological and geophysical survey reports which were conducted during resource exploration. Field investigation was conducted on the quarry to give an insight on the geohazards inherent in the rock mass as a result of the high carbonate content and highly porous nature of the Plesistocene coral limestone rock mass as well as analyze the risk they pose to the operations in the quarry. The assessment involved physical observation to identify potential hazard zones, conditions of slope faces, and types of geological features. Previous geological reports that were done during resource explorations also gave further insight on areas of the site that are yet to be quarried. Fig. 6 illustrates the general workflow process in this manuscript. Data collected includes the lithology, physical characteristics of rock, structural features, slope face characteristics, and potential hazard zones. Data analysis includes the formation processes of the identified geological features and how they contribute to hazards, as well as stability analysis of the slopes.

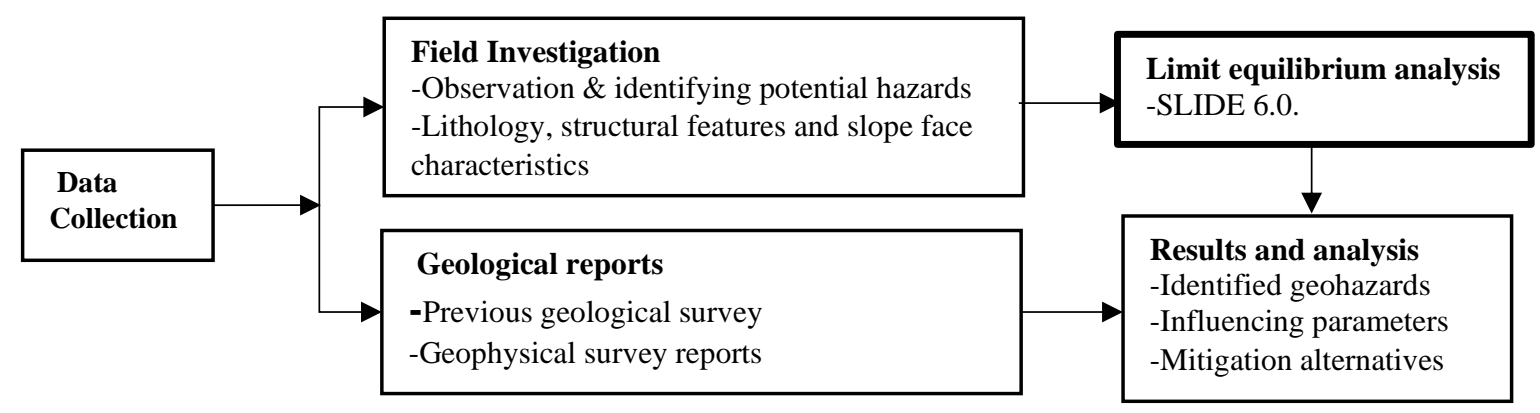

Fig. 6. The workflow processes.

\section{RESUlTS AND DISCUSSION}

Pleistocene coral-reefs and the Pleistocene sands bars form the two primary geological units within the quarry area, the sandbars being lenticular, erratic, and oriented parallel to

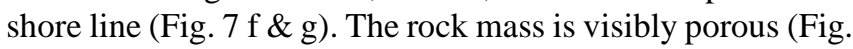
7 d \& e) with no defined bedding/foliation. Discontinuities are not well defined except for traces of topsoil washed down the rock pores and fissures leaving vertical traces of water infiltration paths seen on the slope faces. The northern side of the quarry has a thin topsoil layer less than a meter thick (Fig. 7 a) hence it's mostly high-grade limestone. Towards the eastern side, the topsoil has been washed down deeper forming a layer of between 1-3 m thick mixture of limestone and soil (Fig. 7 b) To the south of the quarry, there exists a sandy coral layer whose thickness is an average of $4 \mathrm{~m}$ below the topsoil (Fig. 7 c). The identified geohazards in this study are grouped into two major categories i.e., unstable slopes/rock failure and karst features.

\section{A. Unstable Slopes}

Slope instability is one of the major challenges encountered in mining as well as civil engineering projects. The risk of instability increases with slope height and angle. Other important factors are the geological structure of the rock mass such as rock strength and presence of discontinuities. Potentially unstable slopes in the quarry area are in the form of overhanging rock layers due to undercutting, planar failure, toppling failure, rockfall, and raveling.

\section{B. Bench Undercutting}

In some sections of the quarry where a soft layer exists, like at the southern end of the quarry where there is a sandy layer, it is often noticed that there is an excessive excavation of the lower soft layer of the bench resulting in a hanging out a hard layer at the top. Besides over quarrying of the soft sandy layer, on the mined-out areas of the quarry, the coral sand layer gets weathered faster than the coral limestone, leaving out overhanging a potentially dangerous overhanging layer. Since there's no supporting structure at the base, there's a risk of collapse of the top layer as illustrated in Fig. 8 .

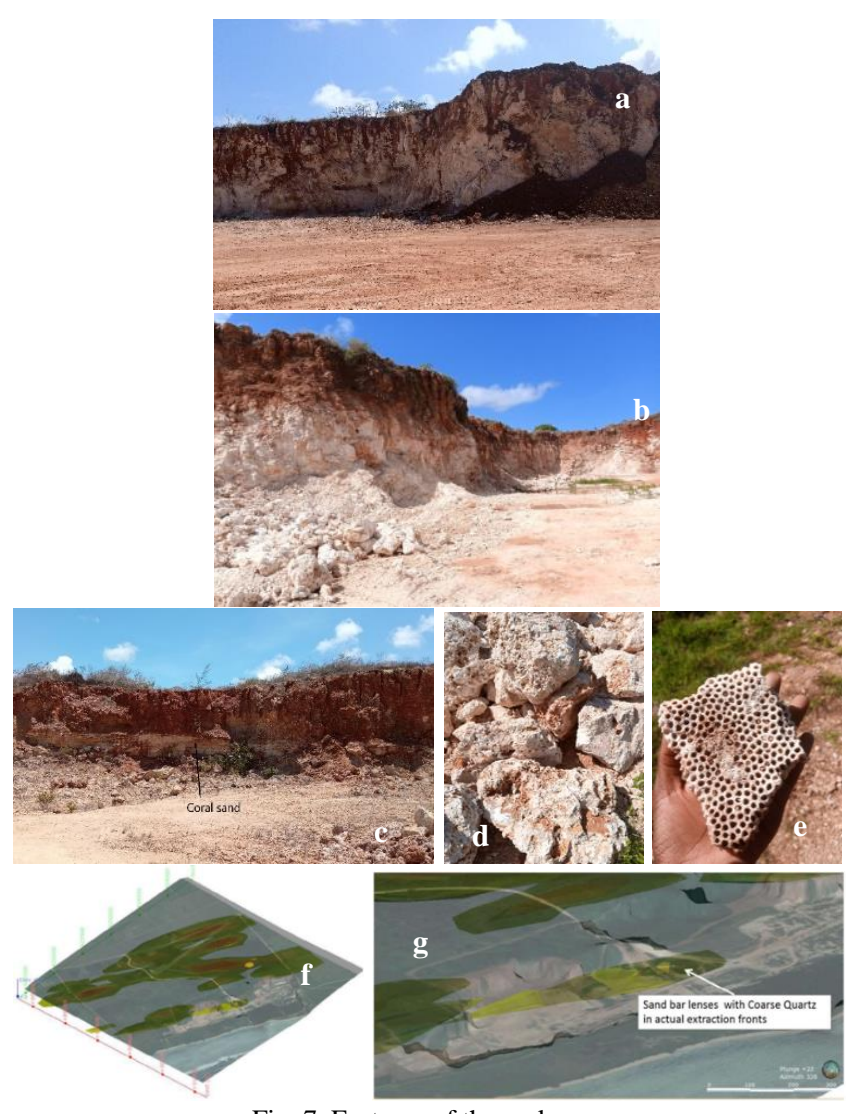

Fig. 7. Features of the rock mass. 


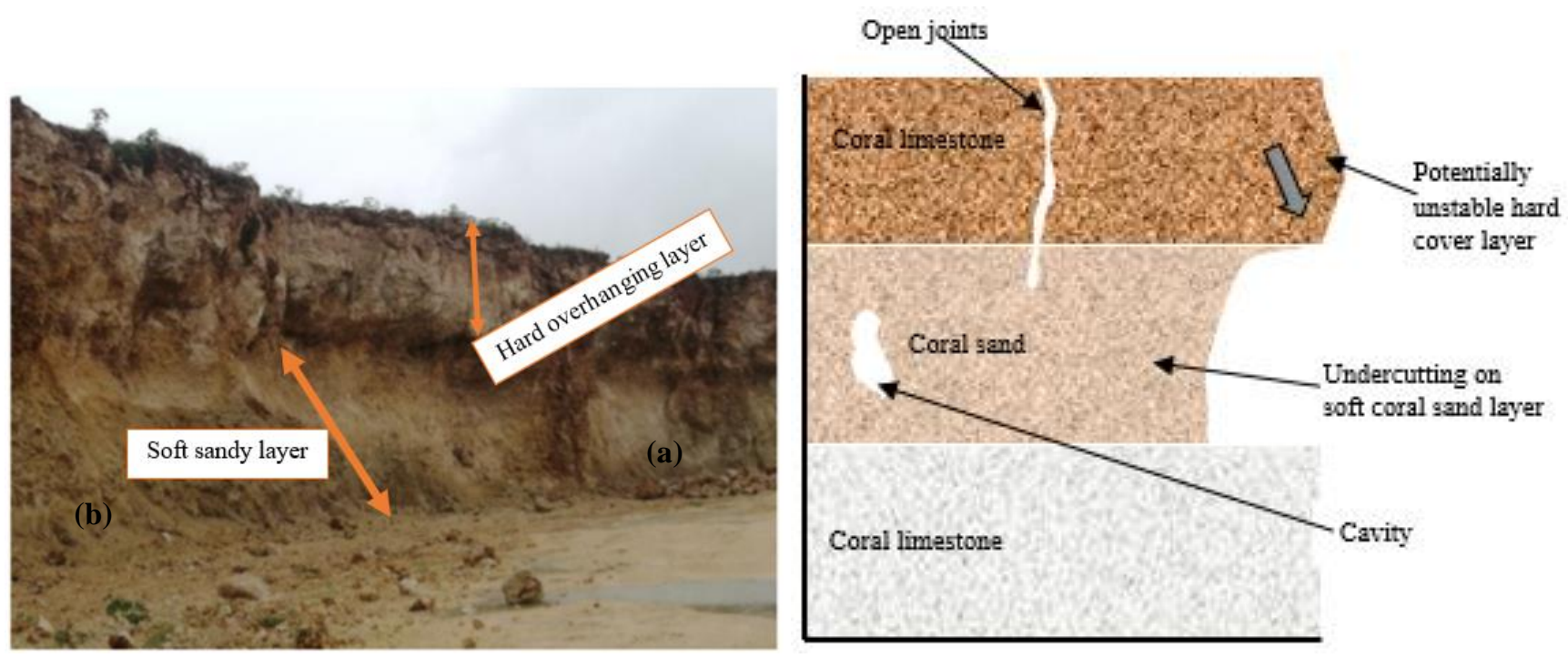

Fig. 8. Bench undercut.

\section{Planar Failure}

Plane failure generally occurs in stratified sedimentary and meta-sedimentary rock formations when a structural discontinuity plane daylights on the rock face at an angle smaller than the slope face angle but greater than the angle of friction of the discontinuity surface [31]. This failure type is common during rainy seasons when rainfall makes the structural surfaces soften further expanding the original cracks of the slope rock mass expand or produce new cracks, gradually disintegrating and sliding out along the structural plane [32]. However, in carbonate rock mass subjected to karstification, the development of structural planes such as faults and cracks is more complex and not easily identifiable. Xiansong et al. [33] in their study of failure modes of karst breccia, tried to explain plane failure in karst as being a result of the combined effect structure plane and circular arc as illustrated in Fig. 9.

The failure in Fig. 10 occurred as a result of the opening of vertical fractures along the planes.

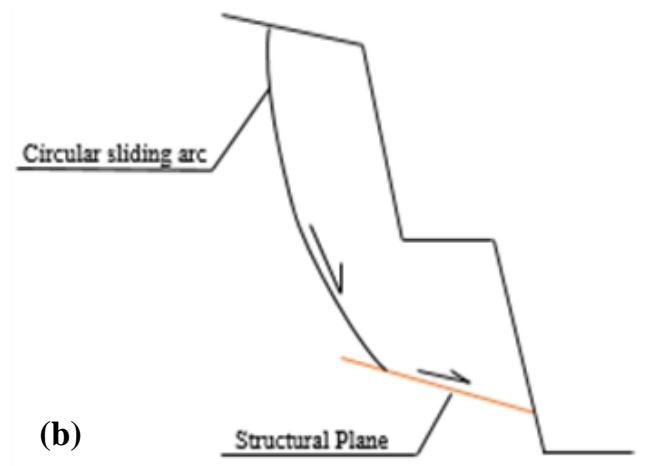

Fig. 9. Principle of planar failure: (a)Basic plain failure (b)Combined effect of structural plane and circular arc
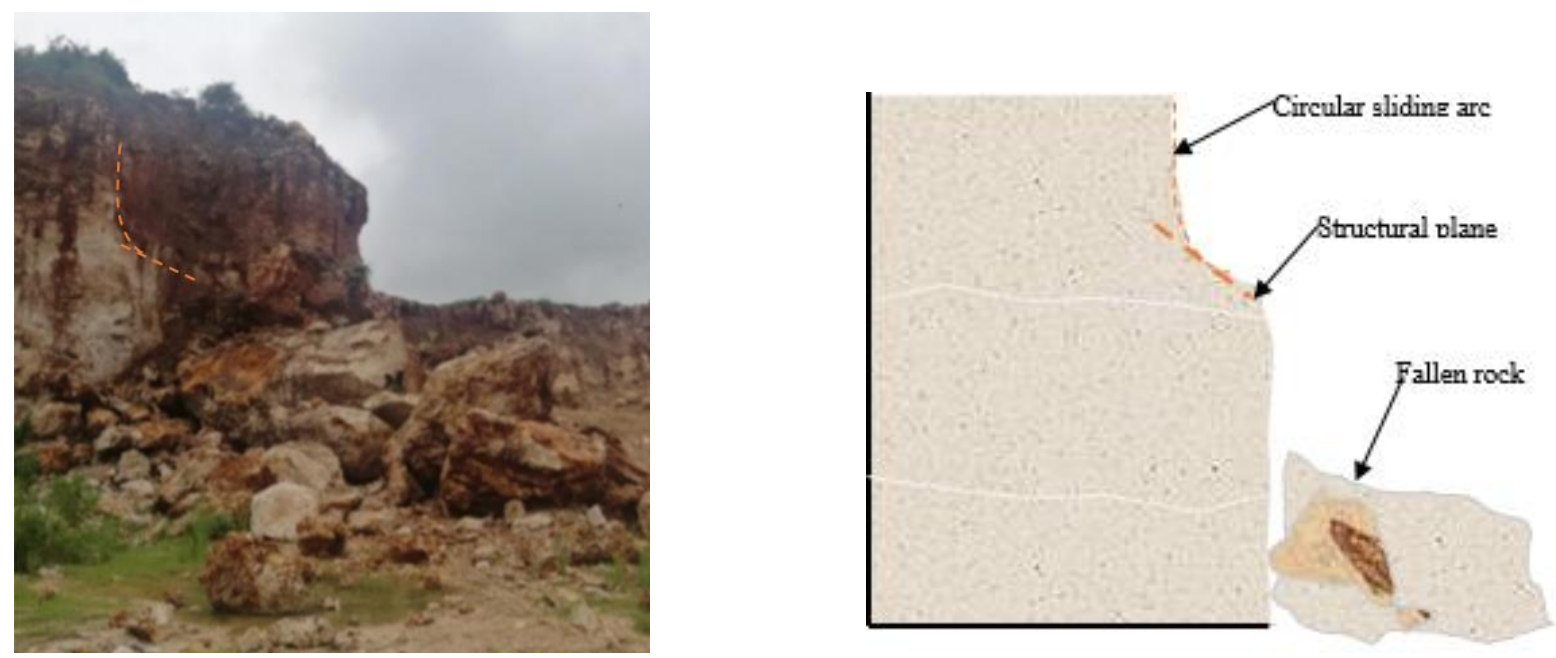

Fig. 10. Planar failure. 


\section{Rock Fall}

Rockfall is instigated by the presence of vertical joints through which water seeps during precipitation. The seeping water washes down some topsoil with it as well as dissolving the carbonate limestone, thus widening the joints. The washed-down soil deposits at the bottom of the joint, increasing the tensile stress there as the soil swells and contributing towards pushing the split rock further outwards. With time, the rock breaks away from the main rock mass as is likely to happen in Fig. 11 (a). As observed from the assessment, the risk of rock rockfall is high a few days after blasting. Fig. 11 (b) shows a large block of approximately 120 tons split from the bench face about two days after blasting. The same is exacerbated by the presence of karst joints which result in the rock mass being further weakened by blast vibrations.

\section{E. Toppling Failure}

Toppling failure occurs when rock columns bend forward under their own weight and transfer the load to the underlying columns giving rise to tensile and bending compressive stresses, thus, initiating failure when the tensile (bending) stress in the toe column exceeds the tensile strength of the

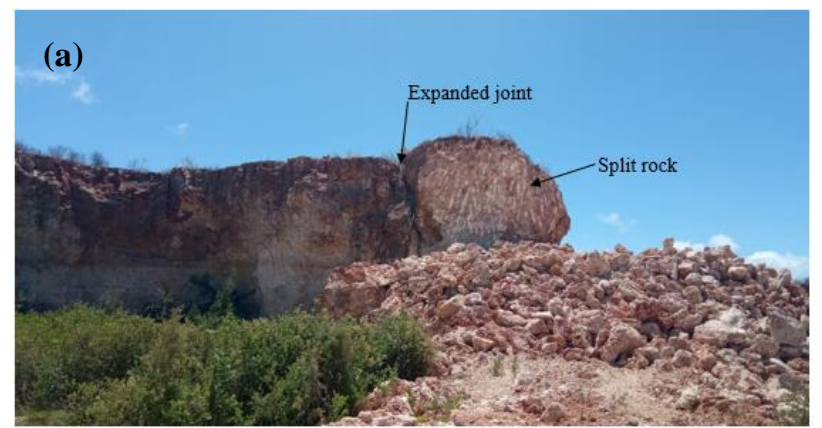

rock [34]. Toppling failure in a rock mass subjected to karst is fostered by the presence of high discontinuity planes at high gradient [35] and rainfall aggravates the process just as in-plane failure mode discussed above. In Fig. 12 the bench at one corner begins to split in toppling failure.

\section{F. Bench Collapse}

The stability of roofs of caves is largely a function of its unsupported span and rock mass quality. Caves buried deep underground remain stable without additional support. However, smaller caves in highly fractured rock zones beneath very thin roof slabs tend to be unstable. This is the case with the coral limestone rock mass in this study. Caves and cavities occur near the surface where the roof slab is relatively thin and highly susceptible to failure. The rock mass is also weakened by weathering, having properties of both soil and rock. Fig. 13 (a) shows a bench that collapsed about $3 \mathrm{~m}$ below its original level. The thin slab (Fig. 13 (b)) overlying a cave gets weakened due to insufficient support for the overhanging weight leading to the roof collapsing. When the cave is underneath a bench as is the case here, the consequence is a collapse of the bench and rock material falling into the cave.

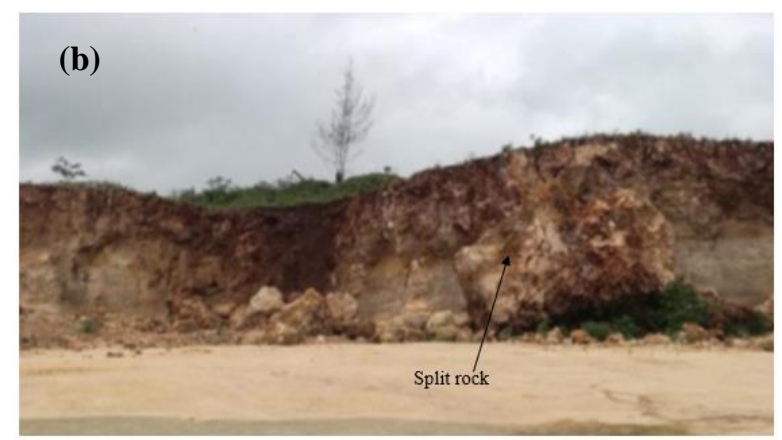

Fig. 11. Rock fall: (a) Rock at risk of falling; (b) Split off rock block.
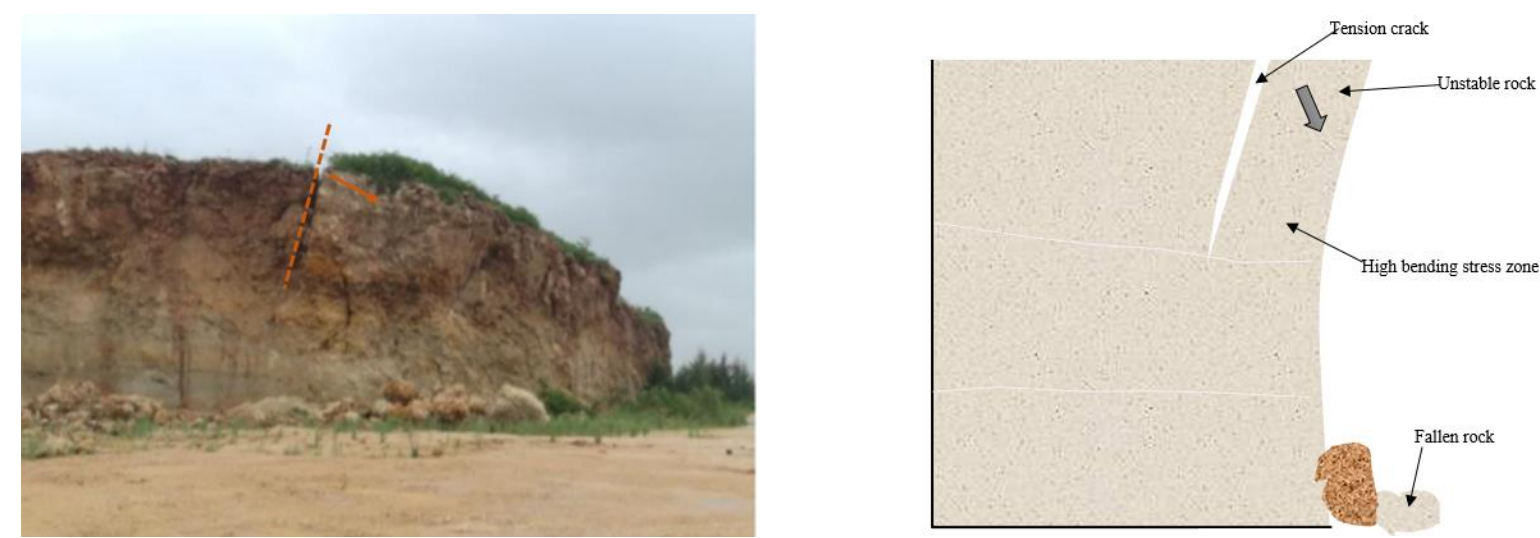

Fig. 12. Toppling Failure.
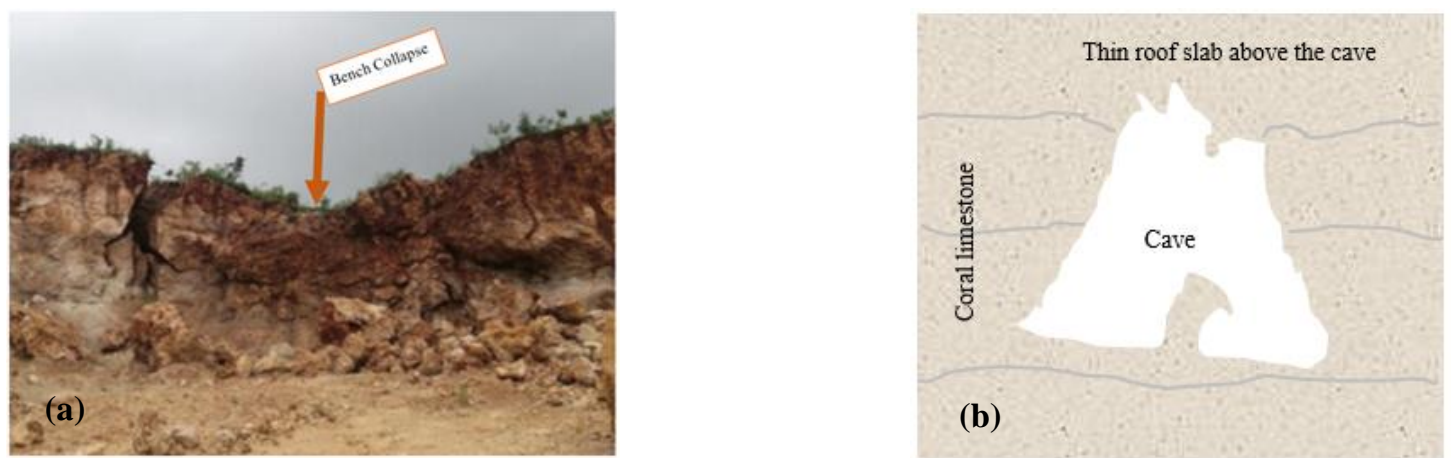

Fig. 13. Collapsed cave leading to bench collapse. 


\section{G. Raveling}

Raveling failure occurs on highly jointed slope faces, often as a result of excavation disturbances and weathering [36]. In the study of instability mechanisms affecting carbonate flysch, Cano \& Tomás [37] define raveling as gradual erosion of particles or blocks of weatherable lithologies which accumulates weathered marly deposits at the toe of the slope. This coral limestone rock mass is subjected to karstification, the rock pores and fissures being infilled with soil on the topmost layers making the rock structure composition of rock and soil as can be seen in Fig. 14 (a). The benches are also subvertical (Fig. 14 (b)) leaving the weaker rock layer at the top susceptible to raveling (Fig. 14 (c)).

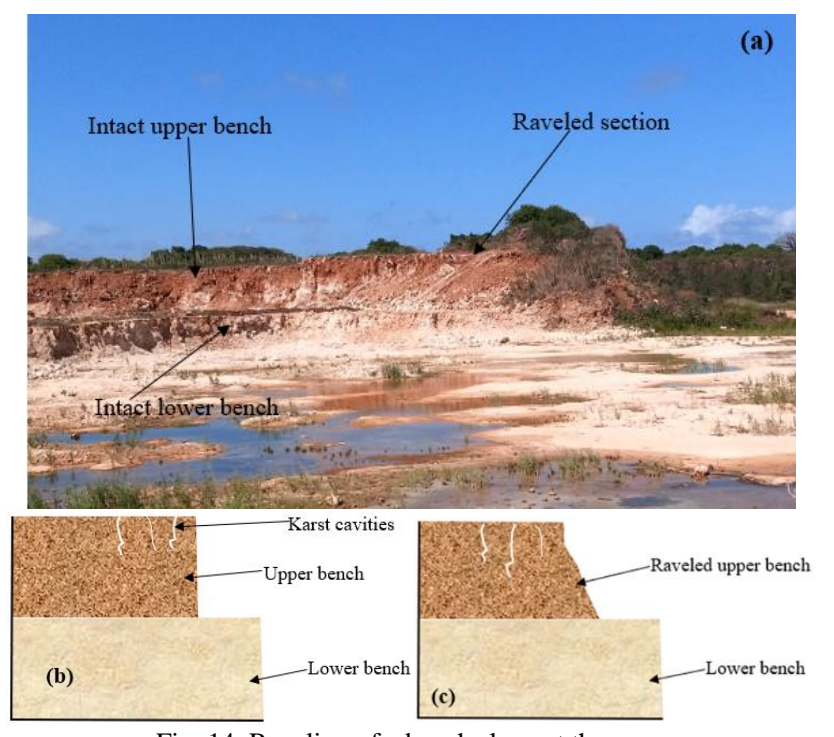

Fig. 14. Raveling of a bench slope at the quarry.

\section{H. Karst Features}

Karst is a distinctive geomorphological feature that indicates dissolution of underlying rocks by carbonic acid present in surface or groundwater with high $\mathrm{CO}_{2}$ and $\mathrm{O}_{2}$ content to produce a network of enlarged joints and cavities through which the water then preferentially flows [38]. The slope face in Fig. 15 shows karstification traces due to the effect of percolating water over a long period of time. Cavities and voids are visible within the rock mass and are a direct indication of further cavities and voids. The karst features tend to have an effect on the quality of blasting therefore the rock competency should be keenly monitored from the drilling log and plan the blast design accordingly. Continued erosion of the quarry slopes over time by karstification compromises the stability of the quarry slopes.

\section{Voids and Cavities}

Cavities in this rock mass have developed as a result of groundwater flowing through the highly porous rock, producing a network of enlarged cavities through which water preferentially flows. Voids as in Fig. 16 (a) pose a danger to safe blasting in that the void pocket could be overcharged with explosives resulting in shooting of fly rocks to a longer distance. The cavity in Fig. 16 (b) is oriented horizontally. It can lead to failure of the bench in case it's more extensive. The long-term stability of quarry slopes postclosure is also affected by the presence of voids/cavities in the rock mass.
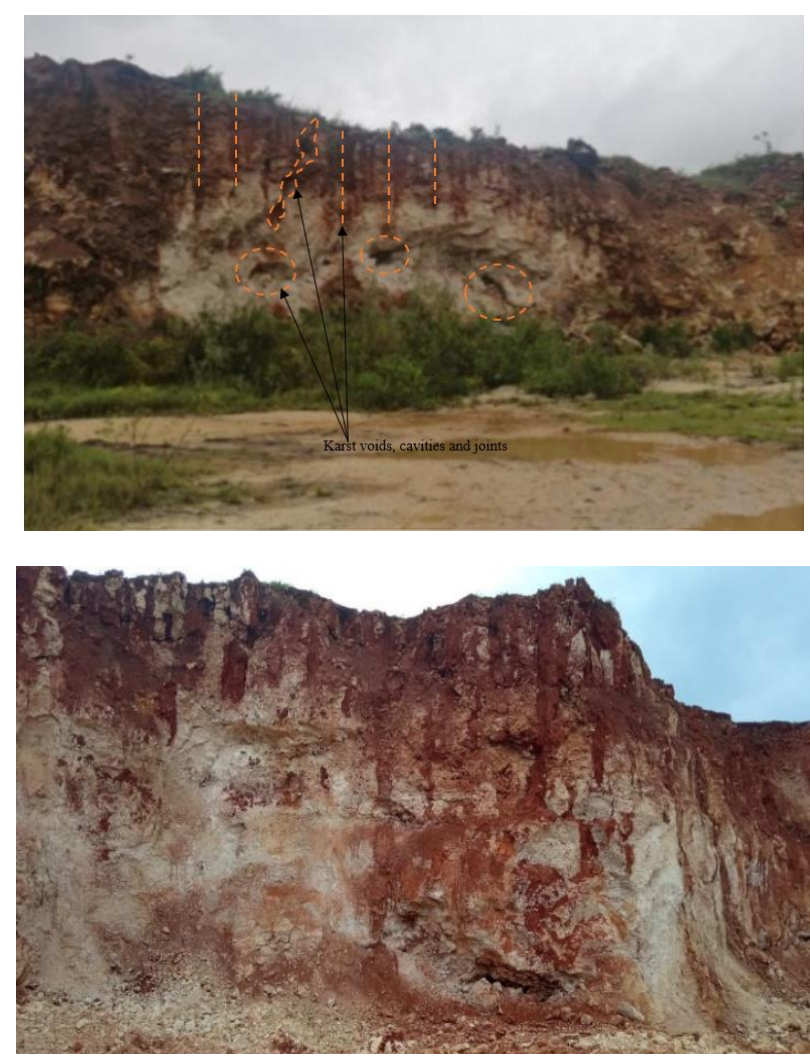

Fig. 15. Karstification on slope face.

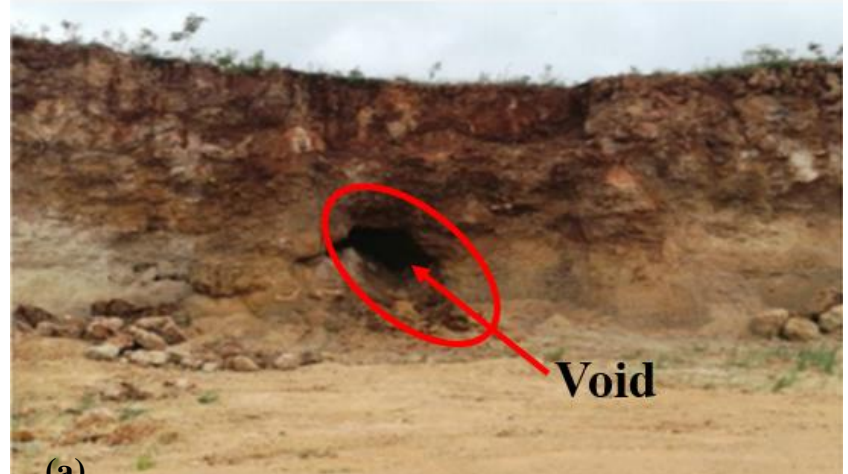

(a)

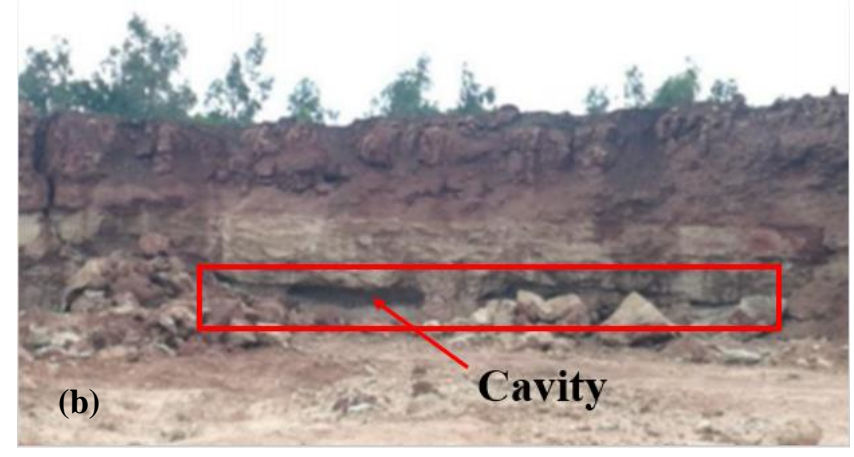

Fig. 16. Voids and Cavities.Caves

When cavities and voids get enlarged over time to the extent of allowing some access they are called caves[38]. Karst caves at Vipingo Quarry are naturally created when rainwater dissolves the limestone as it percolates to the ground. The caves in production areas pose a challenge to safe blasting, and some get destroyed when the rock is mined out. However, some caves shown in Fig. 17 have been used by local communities for centuries and are thus preserved by the company as a cultural heritage site. They have remained stable over time especially because there's very little tectonic 
activity in the coastal region. Further study is however required to assess stability over time.
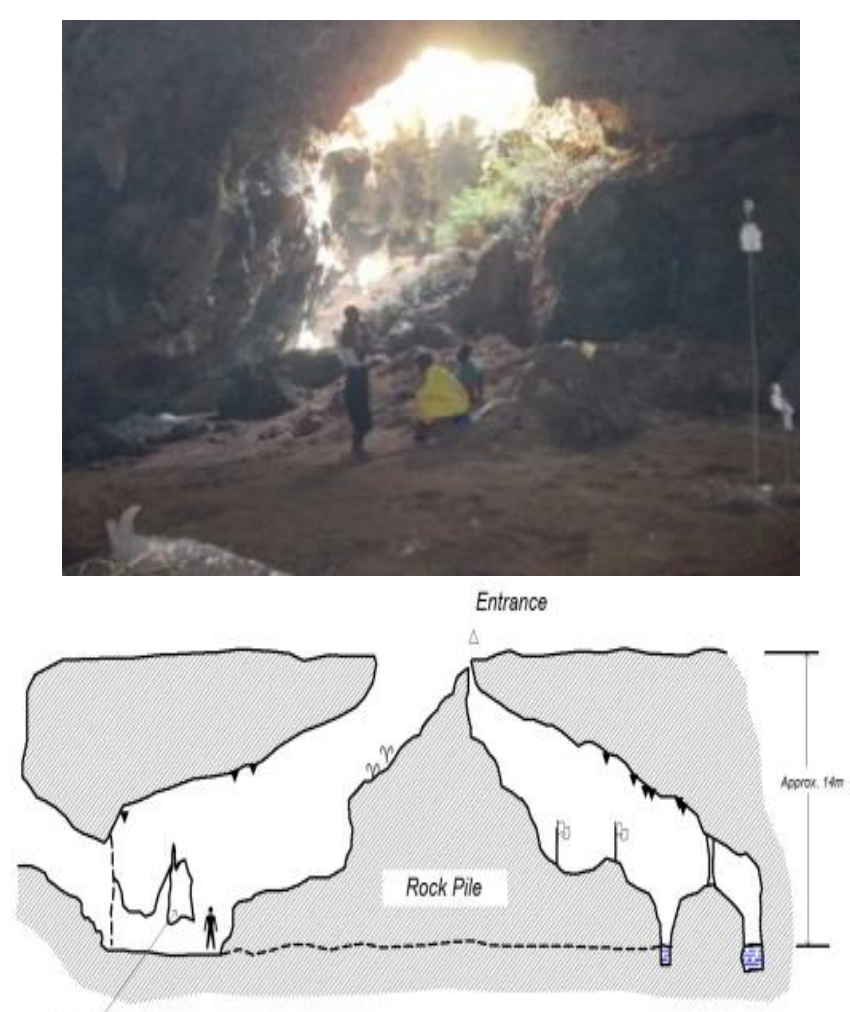

"Letter box"

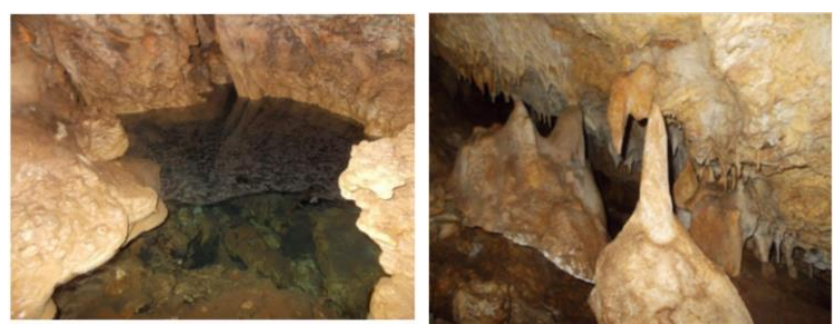

Fig. 17. Caves (Images from a report by Cave Exploration Group East Africa[39]).

\section{J. Sinkholes/Dolines}

Sinkholes (dolines) tend to be very distinctive landforms in carbonate rock masses representing a significant connection between the ground surface and the subterranean world. Bérest [40] defines sinkholes as basically closed depressions, generally circular in plan, with internal drainage and in most cases a direct connection with the underground. Gutiérrez et al. [41] classified sinkholes into two classes: solution and subsidence sinkholes. Subsidence sinkholes were further divided into three groups based on the mechanism of subsidence: collapse, suffusion, and sagging. The categorization leads to the classification of sinkholes into six main types based on their genetic processes and morphology as outlined in [16]. Fig. 18 shows a shallow pool of water on a bench, an indication of possible cavities in the rock mass underneath. When the water trapped on the bench percolates, it causes swelling in the clay-filled karst cavities leading to a lubrication effect and a decrease in stability of the bench. The likely formation mechanism of the sinkhole is suffosion which is the downward erosion of unconsolidated sediments and its consequent settling [42].

Dolines are also prevalent around the center to the south of the quarry land and can be attributed to the presence of coral sands. Due to limitations by the thick bushes, a photograph of a doline was not obtained. However, a plan of one of the dolines in Fig. 19 was adapted from a report by the Cave Exploration Group East Africa [39] to show its rough size. The depth is $2 \mathrm{~m}$ on average.

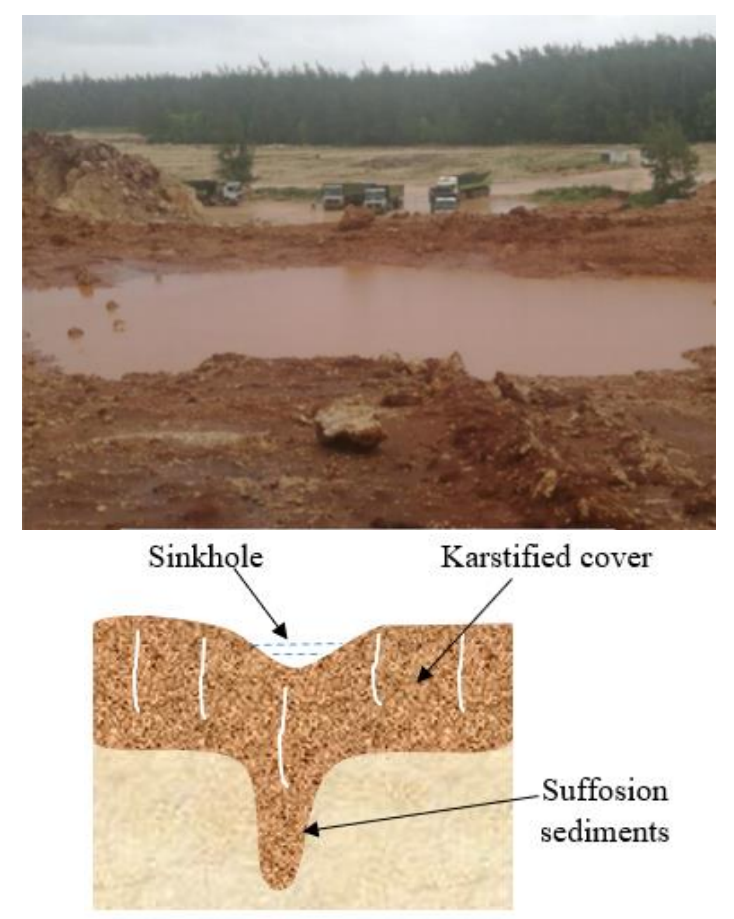

Fig. 18. Sinkhole.

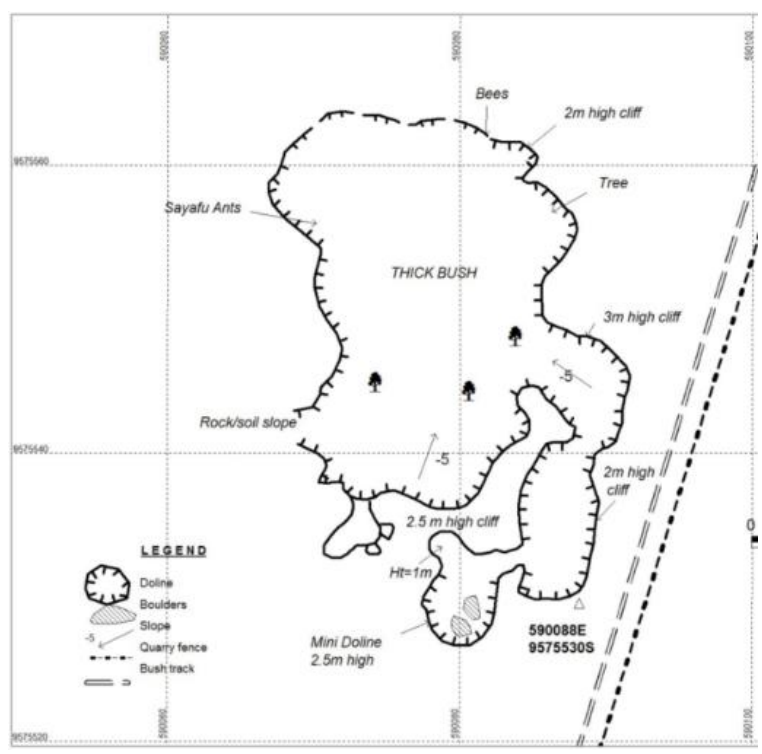

Fig. 19. Plan view of a doline within the quarry.

\section{K. Stability condition of the Slopes}

The geology of the quarry area is represented by three major lithological units which are described in this paper as high-grade limestone (HGL) (Fig. 22), weathered limestone (WL) that is subjected to karstification forming the upper layer up to $3 \mathrm{~m}$ depth (Fig. 21), and also a region with weathered rock underlain by coral sand (CS) (Fig. 22). The stability conditions of these three regions were analyzed using Limit Equilibrium (LE) software SLIDE 6.0. The material properties for the lithological units are as shown in TABLE . The overall slope height of the quarry mine is $20 \mathrm{~m}$, 
which is the maximum height above sea level since mining below sea level is prohibited by Kenyan law.

TABLE I: MATERIAL PROPERTIES

\begin{tabular}{ccccc}
\hline \multicolumn{5}{c}{ TABLE I: MATERIAL PROPERTIES } \\
\hline Channels & Units & HGL & WL & CS \\
\hline Dry Unit Weight & $\mathrm{kN} / \mathrm{m}^{3}$ & 21.44 & 18.10 & 18.10 \\
Cohesiom & $\mathrm{kPa}$ & 56 & 45 & 45 \\
Friction angle & $\left({ }^{0}\right)$ & 31.1 & 26 & 26 \\
\hline \hline
\end{tabular}
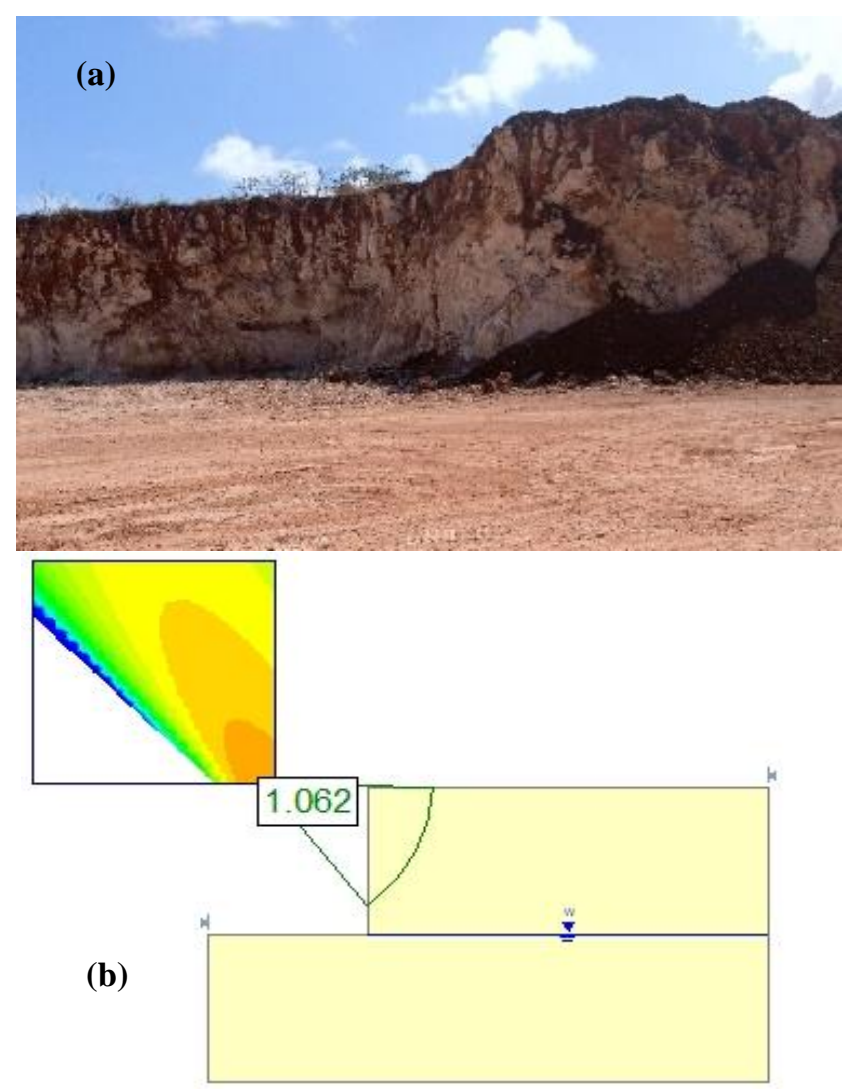

Fig. 20. Region of high-grade limestone(HGL).

The stability of the slope is generally determined by a stability index called the factor of safety (FoS). In geotechnical engineering, $\mathrm{FoS} \leq 1$ implies that the slopes are unstable and likely to fail, FoS $=1$ means the slopes are at equilibrium, and FoS $\geq 1.2$ is considered stable and safe in shallow mines. The safety factors obtained for the three major lithological units for a working slope height of $20 \mathrm{~m}$ are 1.062 for the high-grade limestone(HGL) region, 1.086 for the region with weathered limestone (HGL-WL), and 1.105 for the region with coral sand (HGL-WL-CS). These values are below the recommended slope safety factor of 1.2. A slope optimization analysis carried out (Fig. 23) shows that a higher safety factor is achievable by reducing the slope angle. A slope angle of $76^{\circ}$ is optimum for HGL, $79^{\circ}$ for HGL-WL, and $80^{\circ}$ for HGL-WL-CS, which gives an average overall slope angle of $78^{\circ}$. Engineered slopes in this type of rock mass with greater heights will require less steep angles to keep the slopes stable and safe for operations.
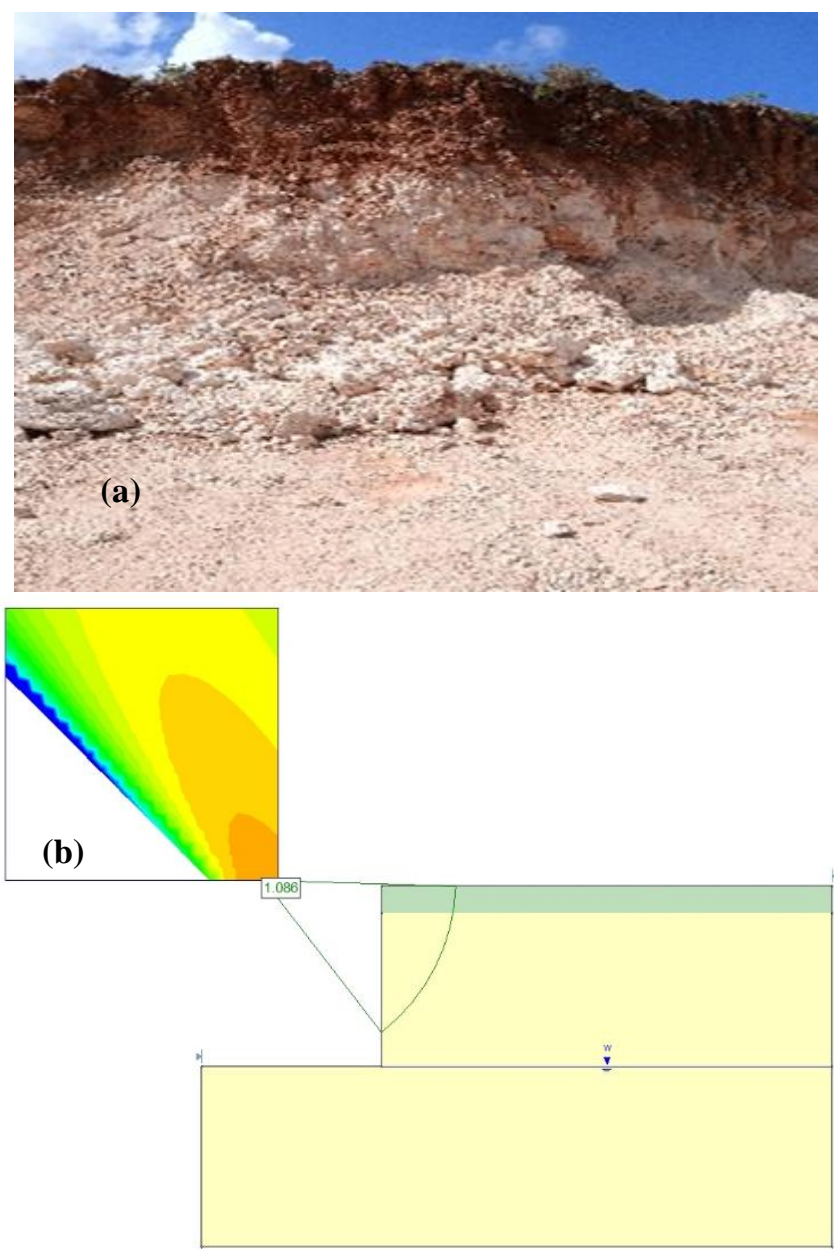

Fig. 21. Weathered limestone region (HGL-WL).
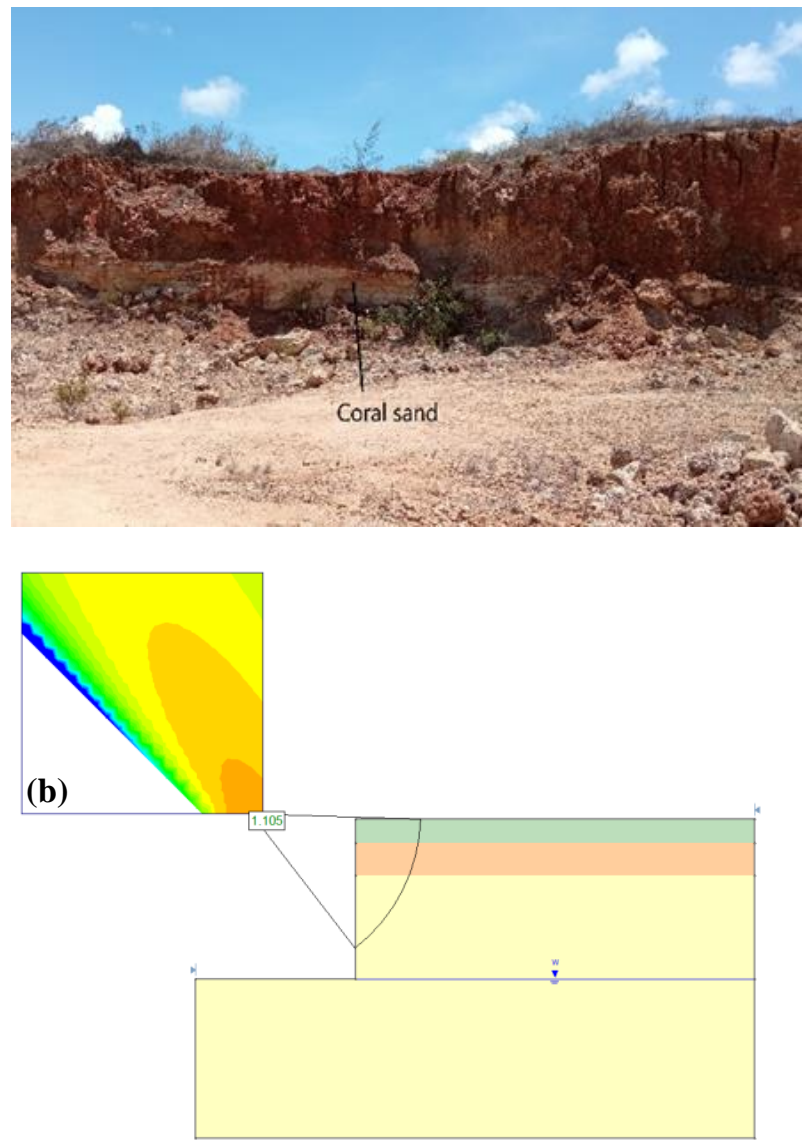

Fig. 22. Weathered region underlain with coral sand (HGL-WL-CS). 


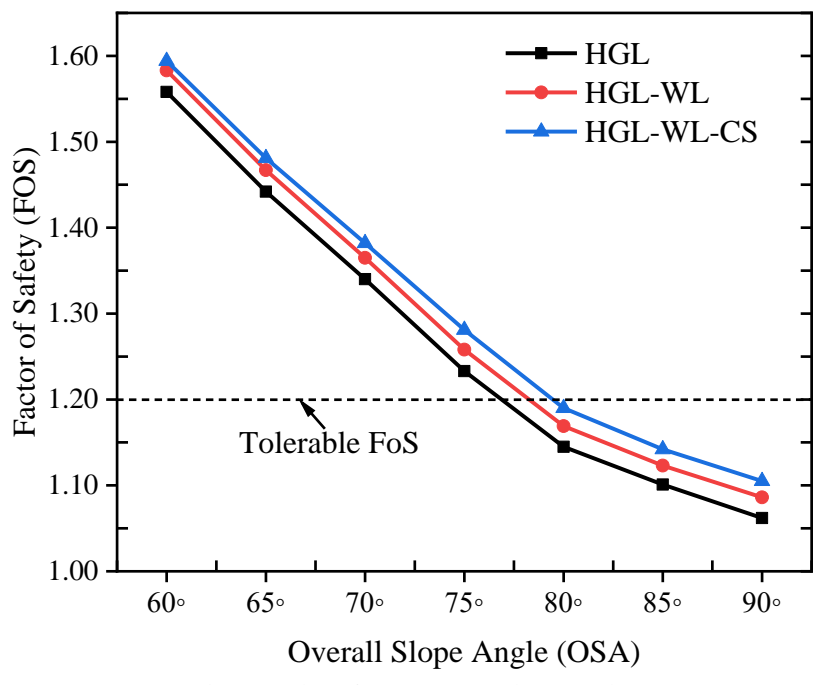

Fig. 23. Plot of FOS versus slope angle.

\section{Mitigation AND RECOMMENDATIONS}

Specific hazards and impacts inherent to karst environments are largely related to their endemic geomorphological and hydrological peculiarities determined by the soluble nature of the bedrock [41]. Human activities such as quarrying generally bring about a great variety of anthropogenic effects, including degradation of the karst landscape, destruction of the epikarst, loss of karst landforms, and occurrence of sinkholes [43]. Remediation and mitigation are the main methods applied to alleviate geohazards. Remediation refers to the application of a physical restraint to contain deterioration of rock. Methods include rock bolting and/or shotcrete, or building a metal, concrete, or stone retaining wall. Remediation methods especially retaining walls end to be costly and are often used in very small areas. In the application of rock bolting or shotcrete solutions, further deterioration of the rock with time make the methods impractical over time[44]. Mitigation practices on the other hand aim at allowing the rock to fail but minimizing the associated negative impacts. Mitigation methods include different types such as modification of slope geometry, catchment benches and ditches, berms and/or fences, draped wire mesh, or rockshed structures [45].

The most prevalent hazard in the current study is slope movements and cave collapses. Due to the active karstification processes in the area, it is best to consider mitigation of impacts to ensure safe quarry operations and also the safety of those who traverse through the quarry land. It can be seen from the images that mining is done with subvertical benches making the slopes highly susceptible to various failure types. It is therefore important that the slope angles of the mined-out areas be reduced to safer values as recommended in the slope angle optimization analysis. Undercutting of the slopes during excavation should be avoided by doing a top-down approach on the slope. In the process of reducing the slope angles, it is recommended to construct berms as they are very effective in arresting rock falls.

The rock mass being highly porous means water seepage rate is quite high hence faster weathering. Revegetation of slope faces is therefore crucial in holding the soil particles together and slowing down karst and overall weathering processes. Drainage channels should be constructed on the slope to carry water down to ditches constructed at the toe of the slope. The danger posed by hidden voids, cavities, and caves to safe blasting should not be underestimated. When drilling blast holes, the drill operator can tell when he encounters avoid so as to do a better estimate of the charge. The identified caves should be constantly monitored to ensure the public is not exposed to any unforeseen danger. It is recommended that for this quarry site, a karst mapping using geophysical methods should be done to identify caves beforehand in order to plan blasting accordingly and also plan for the most suitable mitigation methods.

Studies on slope stability have not given proper attention to karst processes and their likely influence on stability on slopes occurring in karst environments. The scientific community should therefore focus more on understanding and developing analysis tools that take into consideration karst-related factors that trigger and influence the development of slope instability. Besides the engineering efforts, the public residing in karst environments should be educated on good practices for safe living within such an environment.

\section{CONCLUSION}

Geohazard identification, assessment, and mitigation in a karst environment requires much more effort than in other terrains as a result of the underground active processes mainly governed by water movement and are often not directly observable. Furthermore, the spatial and temporal distribution of karst features is also highly unpredictable hence environmental impact assessments require the evaluation of many additional factors with complex interrelations. Going forward, interactions between humans and karst environments will increase as a result of a growing population seeking land for settlement, and also putting up infrastructure projects for water and energy supply. The pressure on karst ecosystems will therefore continue growing contributing further to a higher frequency and intensity of environmental impacts and induced hazards.

In this work, Vipingo Coral limestone quarry was selected as a case study to evaluate and give insight on karst induced geohazards inherent in the rock mass that is in abundance along Kenya's coastal region. The study has identified geohazards and classified them into two major categories namely unstable slopes (rockfall, planar \& tolling failures, raveling) and karst (sinkholes/dolines, void, cavities and caves). The development processes of the geohazards clearly reveal that karst features have a substantial contribution to instabilities in this rock mass. The quarry in this case study is shallow with a slope height of $20 \mathrm{~m}$. The safety factor obtained from Limit Equilibrium analysis is lower than the tolerable value of 1.2 hence the slopes are not quite safe. For greater slope heights engineered in this type of rock mass, instability chances could be higher. Mitigation methods have been suggested to minimize the impacts of these hazards, majorly by reducing the slope angle based on slope angle optimization analysis and revegetation. This paper, which appears to be the first in Kenya in documenting natural geological hazards associated with karst processes in coral limestone reveals gaps in this kind of knowledge in the 
country. This manuscript should encourage more researchers to document similar information for the sake of advancing knowledge about the geology of Kenya as well as pointing out available solutions to the geo-engineering challenges encountered. Recommendations have been made to the scientific community for more studies to be carried out to further explore the karstification phenomenon and mitigate potential hazardous impacts.

\section{DECLARATION OF COMPETING INTEREST}

The authors declare that they have no known competing financial interests or personal relationships that could have appeared to influence the work reported in this paper.

\section{ACKNOWLEDGMENT}

Special regards to Vipingo quarry management team for granting access to the quarry for a physical study and data collection.

\section{REFERENCES}

[1] D. Ford and P. D. Williams, Karst hydrogeology and geomorphology. John Wiley \& Sons, 2013.

[2] F. Gutiérrez and M. Gutiérrez, Landforms of the Earth. 2016.

[3] F. Gutiérrez and A. H. Cooper, "Surface Morphology of Gypsum Karst," Treatise Geomorphol., vol. 6, pp. 425-437, Jan. 2013, doi: 10.1016/B978-0-12-374739-6.00114-7.

[4] W. White, Geomorphology and hydrology of karst terrains. Oxford Univ. Press, 1988.

[5] T. Stokes, P. Griffiths, and C. Ramsey, "Karst geomorphology, hydrology, and management," Compend. For. Hydrol. Geomorphol. Br. Columbia, L. Manag. Handb., vol. 66, pp. 373-400, 2010.

[6] D. C. Ford and P. W. Williams, Karst geomorphology and hydrology. Unwin Hyman London, 2007.

[7] R. G. Maliva, "Karst," in Aquifer Characterization Techniques, Springer, 2016, pp. 545-570.

[8] D. C. Culver and T. Pipan, The biology of caves and other subterranean habitats. Oxford University Press, 2019.

[9] B. Komac and M. Zorn, "Geohazards," in Encyclopedia of Natural Hazards, P. T. Bobrowsky, Ed. Dordrecht: Springer Netherlands, 2013, p. 387.

[10] J. C. Gill and B. D. Malamud, "Anthropogenic processes, natural hazards, and interactions in a multi-hazard framework," Earth-Science Rev., vol. 166, pp. 246-269, Mar. 2017, doi: 10.1016/J.EARSCIREV.2017.01.002.

[11] K. S. Johnson, "Gypsum karst in the United States," Int. J. Speleol., vol. 25 , no. 3, p. 13, 1996.

[12] M. Parise and O. Bonacci, "Hazards in karst," Sustain. karst Environ. Dinaric karst other karst Reg. IHP-UNESCO, Ser. Groundw., no. 2, pp. 155-162, 2010.

[13] G. Kovačič and N. Ravbar, "Analysis of human induced changes in a karst landscape - the filling of dolines in the Kras plateau, Slovenia," Sci. Total Environ., vol. 447, pp. 143-151, 2013.

[14] M. D. Rose and M. Parise, "Karst Subsidence in South-Centralapu-," vol. 1, pp. 181-199, 2002.

[15] J. Liszkowski, "The influence of karst on geological environment in regional and urban planningL'Influence du Milieu Geologique Karstique sur la Planification Regionale et Urbaine," Bull. Int. Assoc. Eng. Geol., vol. 12, no. 1, pp. 49-51, 1975, doi: 10.1007/bf02635428.

[16] M. Parise, "Rock failures in karst," Landslides Eng. Slopes. From Past to Futur., no. May, pp. 275-280, 2008, doi: 10.1201/9780203885284c21.

[17] UNEP, Eastern Africa-Atlas of Coastal Resources. 1998.

[18] H. Toya, H. Kadomura, T. Tamura, and N. Hori, "Geomorphological studies in southeastern Kenya," Geogr. reports Tokyo Metrop. Univ., vol. 8, no. 8, pp. 51-137, 1973.

[19] L. E. Ase, "Studies of shores and shore displacement on the southern coast of Kenya - especially in Kilifi District.," Geogr. Ann. Ser. A, vol. 63, no. 3-4, pp. 303-310, 1981, doi: $10.1080 / 04353676.1981 .11880045$
[20] T. J. Denaro, R. E. Randall, and R. J. Smith, "Minerals and Energy Resources," Geol. Queensl., pp. 687-770, 2013.

[21] C. J. R. Braithwaite, "Depositional history of the late Pleistocene limestones of the Kenya coast.," J. Geol. Soc. London., vol. 141, no. 4 , pp. 685-700, 1984, doi: 10.1144/gsjgs.141.4.0685.

[22] P. Abuodha, "Geomorphology of the Kenyan coast: Not as a Result of Sea-Level Change alone," no. Figure 1, pp. 1-8, 2004, [Online]. Available:

https://www.oceandocs.org/bitstream/handle/1834/407/1 Abuodha.pdf ?sequence $=1$.

[23] W. Pulfrey, "Geology and Mineral Resources of Kenya (Second Revision)," Geological Survey of Kenya. 1969.

[24] MoALF, "Climate Risk Profile for Kilifi County. Kenya County Climate Risk Profile Series.," Minist. Agric. Livest. Fish., 2016.

[25] Kilifi County, "First Kilifi County Integrated Development Plan 2013 2017," pp. 2013-2017, 2017.

[26] Kilifi-County, "National Drought Management Authority West Pokot County," no. January, pp. 1-14, 2014, [Online]. Available: http://reliefweb.int/sites/reliefweb.int/files/resources/West_PokotJanuary-2014.pdf.

[27] Weather-Atlas, "Monthly weather forecast and climate," 2021.

[28] Weather-Spark, "Average Weather in Kilifi Kenya," 2021.

[29] Climate-Data.Org., "Kilifi Climate (Kenya)," 2021.

[30] J. K. S. Lang'at, "Variability of mangrove forests along the Kenyan coast," Unpublished, no. 20, 2008, doi: 10.13140/rg.2.2.21956.48001.

[31] T. K. Raghuvanshi, "Plane failure in rock slopes - A review on stability analysis techniques," J. King Saud Univ. - Sci., vol. 31, no. 1, pp. 101109, 2019, doi: 10.1016/j.jksus.2017.06.004

[32] Y. Wu, S. He, and X. Li, "Mechanism of action of cracks water on rock landslide in rainfall," vol. 4, no. December, pp. 1129-1132, 2010, doi: $10.1007 / \mathrm{s} 11771$.

[33] Y. Xiansong, X. Liming, X. Dongyou, P. Liangyu, and W. Sixiang, "Engineering properties and slope failure mode of Karst Breccia," IOP Conf. Ser. Earth Environ. Sci., vol. 189, no. 2, 2018, doi: 10.1088/1755-1315/189/2/022046.

[34] D. P. Adhikary, A. V. Dyskin, R. J. Jewell, and D. P. Stewart, "A study of the mechanism of flexural toppling failure of rock slopes," Rock Mech. Rock Eng., vol. 30, no. 2, pp. 75-93, 1997, doi: 10.1007/BF01020126.

[35] A. Santo, S. Del Prete, G. Di Crescenzo, and M. Rotella, "Karst processes and slope instability: Some investigations in the carbonate Apennine of Campania (southern Italy)," Geol. Soc. Spec. Publ., vol. 279, pp. 59-72, 2007, doi: 10.1144/SP279.6.

[36] E. Timur and T. Tamer, "Assessment of rock slope stability with the effects of weathering and excavation by comparing deterministic methods and slope stability probability classification (SSPC)," Environ. Earth Sci., vol. 77, no. 14, pp. 1-18, 2018.

[37] M. Cano and R. Tomás, "Characterization of the instability mechanisms affecting slopes on carbonatic Flysch: Alicante (SE Spain), case study," Eng. Geol., vol. 156, pp. 68-91, 2013.

[38] M. H. Al-Kindi and R. Hird, "A review of natural geological hazards in Oman," Environ. Earth Sci., vol. 79, no. 16, pp. 1-12, 2020, doi: 10.1007/s12665-020-09124-x.

[39] C. H. M. King, "Investigation of the Coral Caves on the Bamburi Cement Ltd Property, Vipingo, Kilifi District, Kenya North Coast 1 st October \& 4 th December 2015," no. April, 2016.

[40] P. Bérest, "Cases, causes and classifications of craters above salt caverns," Int. J. Rock Mech. Min. Sci., vol. 100, no. June 2016, pp. 318 329, 2017, doi: 10.1016/j.ijrmms.2017.10.025.

[41] F. Gutiérrez, M. Parise, J. De Waele, and H. Jourde, "A review on natural and human-induced geohazards and impacts in karst," Earth Sci. Rev., vol. 138, pp. 61-88, 2014, doi 10.1016/j.earscirev.2014.08.002.

[42] M. Parise, Sinkholes, 3rd ed., no. 2014. Elsevier Inc., 2019.

[43] M. Day, "Challenges to sustainability in the Caribbean karst.," Geol. Croat., vol. 63, no. 2, pp. 149-154, 2010.

[44] A. M. Youssef, A.-H. El-Shater, and B. A. E.-H. Mohamed H. ElKhashab, "Karst Induced Geo-hazards in Egypt: Case Study Slope Stability Problems Along Some Selected Desert Highways," in Proceedings of the 1st GeoMEast International Congress and Exhibition, Egypt 2017 on Sustainable Civil Infrastructures, 2017, pp. 149-164.

[45] R. K. Panigrahi and M. Rout, "Rock engineering investigation and remediation for unstable hill rock slope: A new approach.," in Geotechnical and Geophysical Site Characterization: Proceedings of the 4th International Conference on Site Characterization ISC-4, 2013, pp. 1213-1219. 


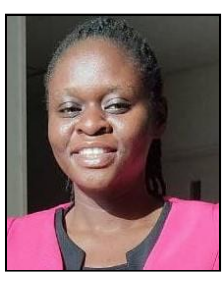

Joan A. Onyango is currently pursuing doctoral studies at Kyushu University. She holds a Master's degree in Mining Engineering from Wuhan University of Technology, China and a Bachelor's Degree in Mechanical Engineering from Jomo Kenyatta University of Agriculture and Technology (JKUAT) in Kenya. Ms. Joan is a Tutorial Fellow at JKUAT's Mining Engineering Department.

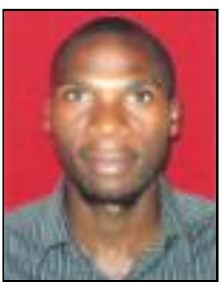

Dyson N. Moses is currently pursuing doctoral studies at Kyushu University, Japan. He holds a Masters degree in Geological Engineering from Science Institute of Dokuz Eylul University in Turkey and a Bachelor's Degree in Geology from University of Malawi. Mr. Moses is a lecturer at, University of Malawi, Zomba, Malawi. 